\title{
THE CONCEPTION AND SIGNIFICANCE OF FACILITATION IN THE STUDIES OF FOREIGN SCIENTISTS
}

\begin{abstract}
The author of the article analyzes the works of foreign scientists, determines the essence of facilitation, and reveals the conception of pedagogical facilitation. In the article the role and skills of facilitative teacher are characterized. It was determined that pedagogical facilitation is a specific type of pedagogical activity of the teacher, which aims to help the student in self-development, self-realization, selfimprovement, to promote his personal growth, the disclosure of abilities, cognitive capabilities.

Keywords: facilitation theory, facilitative teacher, facilitator, Carl Rogers, pedagogical activity.
\end{abstract}

Formulation of the problem. The presence of highly skilled specialists is an important factor in the success of the development of society. Nowadays there are raised requirements for the process of professional training of students, strengthening the practical orientation of training, gaining profound knowledge on specialty, etc. It is important to develop the student's personality - readiness for self-improvement, self-realization, adaptive abilities, flexibility, ability to independently acquire knowledge, communicative skills, mobility, etc.

That is why the study of the main trends in the use of facilitation in the context of the training of specialists in the field of education is an urgent and relevant research task.

Research objectives are to reveal the essence of facilitation, the role and competencies of the facilitative teacher in the studies of foreign scientists.

Analysis of recent researches and publications. The issue of pedagogical facilitation has been given considerable attention in the works of the native scientists (A. Makarenko, S. Rusova, H. Skovoroda, V. Sukhomlynskyj, K. Ushynskyj, V. Shatalov) and foreign scientists (B. Bloom, D. Dewey, A. Combs, J. Komenskyj, C. Rogers etc.).

In the native scientific works, the phenomenon of facilitation is considered mainly from the point of view of psychology in the aspect of the eco-facilitation approach ( $P$. Lushin) and in connection with the psychologist ability to exercise the facilitation impact on a person (G. Ball, O. Kondrashikhina).

It is worth noting that the term "pedagogical facilitation" is relatively new, it does not belong to the traditional categories of pedagogy and psychology. But modern psychological and pedagogical science contains a set of solid theoretical positions that we can use to explore the conception under consideration. To understand the theoretical foundations of the formation of pedagogical facilitation we need to turn to the scientific works of native and foreign scientists, in which the phenomenon under study has its origins, first of all, to the humanistic paradigm of the existence of humanity, which belongs to the number of fundamental ideas of world pedagogy.

The idea in humanism is also reflected in the writings of such foreign scholars as O. Dekroli, D. Dewey, R. Kouzine, $S$. Frené, R. Stayner. The realization of the humanistic approach in foreign countries is associated with the names of A. Maslow, J. Allport, C. Rogers, R. Mey, V. Frankl and others.

The basic approach to the interpretation of the essence of facilitation in teaching was made by $\mathrm{C}$. Rogers, J. Heron and others.

Research presentation. Reviewing the history of origin of facilitation, we should refer to the etymology of the verb 'facilitate', meaning to make easier, to help bring about'. The first known use of facilitate in the meaning defined was in 1599 [3]. In English language the word facilitator in its turn derives in 1775 and associated with the someone who helps to bring about an outcome (such as learning, productivity, or communication) by providing indirect or unobtrusive assistance, guidance, or supervision.
Studying the problem Josie Gregory notes that facilitation is found in many forms of experiential and practical learning such as role modelling, apprenticing and reflective, empirical experimentation [8]. In the twentieth century facilitation is re-emerged within progressive or radical education and expanded hrough the new psychotherapeutic fields such as Gestalt, Psychodrama, therapeutic art and dance and other humanistic personal development approaches. From here it permeated into the adult education field with experiential approaches to learning, particularly in personal and professional development [8].

Facilitation theory, sometimes also called facilitative teaching, is a humanist approach to learning, developed during 1980 s by an influential American psychologist Carl Rogers and other contributors and is best described in his own words: "We know ... that the initiation of such learning rests not upon the teaching skills of the leader, not upon his scholarly knowledge of the field, not upon his curricular planning, not upon his use of audio-visual aids, not upon the programmed learning he utilizes, not upon his lectures and presentations, not upon an abundance of books, although each of these might at one time or another be utilized as an important resource. No, the facilitation of significant learning rests upon certain attitudinal qualities which exist in the personal relationship between the facilitator and the learner" [4]..."We cannot teach another person directly; we can only facilitate his learning" [5].

Facilitation literally means 'easing'. Helping learners realise their capacity to learn is the hallmark of the facilitator, moving education from a delivery of static knowledge to a dialogical relationship where knowledge is co-created. Rogers stated: "We are, in my view, faced with an entirely new situation in education where the goal of education, if we are to survive, is the facilitation of change and learning. The only man who is educated is the man who has learnt to learn: the man who has learned how to adapt and change, the man who has realised that no knowledge is secure, that only the process of seeking knowledge gives a basis for security. Changingness, a reliance on process rather than upon static knowledge, is the only thing that makes any sense as a goal for education" [4, p. 120].

Carl Rogers in his works focuses on two types of learning, which were introduced by earlier scholars rote learning, referring to in consequential consciousness of facts, and experiential learning in daily being, which has meaning and personal importance, it is the result of a common interests, and a recognized relevance of the learned material, often acquired through doing, or at least facilitated by student's active participation in the learning process, and often selfinitiated. Still, this kind of knowledge is difficult to communicate to another. Rogers described the teacher as the key role in the process of learning, as the facilitator of learning. The facilitation here occurs through the teacher's attitudes in his personal relationship with the students. Rogers 
suggested three attitudinal qualities necessary for facilitative practice. They are: realness, what means that the teacher is being himself, not denying himself. The teacher has to be a real person aware of his feelings and able to communicate them appropriately, no matter how exactly does he feel. He should not be just a role in the play of education, "a faceless embodiment af a curricular requirement or a sterile tube through which knowledge is passed from one generation to the next"; prizing, acceptance, trust, that refers to teacher's caring about the student and his acceptance of student's feelings (one that support learning as well as ones disturbing it). It is the trust and prizing of his capacity and abilities as a human being; empathy means that a teacher can understand student's perspective on the process on learning and his reactions from the inside. The accent here is on understanding, not judging or evaluating [4].

Hunter in his research stated that facilitators are people with the skills to create conditions within which other human beings can, so far as is possible, select and direct their own learning and development. A facilitator is a 'process guide who works with a group to assist it to achieve its self-defining purpose [2, p. 118].

Josie Gregory mentioned that the ideological approaches to facilitation emerge out of a particular philosophical framework that espouses the self-directed nature of learning. These values guide and direct intentions that act as a blueprint for facilitator style and interventions as well as for learning outcomes [8]. Heron actually identifies participant qualities towards which the practitioner interventions are aimed, which underpin both facilitator practice and participant ideals. The facilitator works towards: 1 self-direction and co-operation; 2 informed judgement and open communication; 3 self-development and social change; 4 emotional competence and interpersonal sensitivity; 5 self-awareness and social perception; 6 celebration of self and others [1]. Facilitators act as guides helping participants explore their own self knowledge, self-development, self-realization, selfimprovement, to promote his personal growth, the disclosure of abilities, cognitive capabilities, social knowledge.

Developing personal functional capacities, increased self-knowledge, charismatic training and grounding in and preparation of your subject matter; and development of a positive self-concept, self-esteem, self-presentational capacities, below some specific personal qualities, J. Heronconcidered the facilitators need to have: authority, what means being able to hold and use authority (both positional and expert authority) without displacing your personal distress on to others; confrontation, what means to confront supportively, work with projections and defence that emanates from the group; care, an ability to show compassion, are genuine and empathetic in yourwork; range of methods is ability effectively deal with deep regression, catharsis and transpersonal aspects of group life, and have a wide repertoire of techniques and exercises for personal and interpersonal development; orientation, when you can provide clear conceptual maps as required; respect for persons, you respect the autonomy of the person and the rights of individuals to choose when to change/grow; flexibility of style, when you move deftly and flexibly as the situation demands, between interventions in one dimension, between dimensions and between modes so that the group dynamic and individual learning can flourish [1]. It seems than not all the above qualities are necessary for all facilitators nor for all facilitated events. It much depends on the type of facilitation required, but they are all listed above to demonstrate the breath and depth of facilitation skills.

Even the most innocent facilitation of personal development will touch on emotional, spiritual, and imaginal levels if one is working holistically. The skillof containment of emotional expression, containment of fear of getting it wrong, or being vulnerable in front of others all require a nurturing, yet respectful detachment from the group agenda [8]. J. Heron highlighted this point: The enemy of presence is anxiety. Actors often have a lot of fear before going onto the stage. It usually goes once they are out front, with the secure content of rehearsed lines which they can fill with presence. But extempore speech in everyday life may often generate a lot of subtle anxiety. For some facilitators this hurdle can be overcome by rehearsal or by deep relaxation exercises but for others some significant personal development work may need to be done before presence in the face-to-face situation can be consistently achieved. Hence emotional competence is one of the central planks on which facilitator presence sits alongside other attributes presented here [1].

Other tasks of teachers include establishing a pleasant atmosphere in the classroom and thereby facilitating learning and acquisition of new ideas by reducing possible negative effects of external factors. A facilitative teacher should also be open to new ideas, listen to students, pay as much attention to his relationship with the students as he does to the content he is teaching, encouraging learners to take responsibility for their learning and actions and to take selfevaluation as the highest form of evaluation. He should also use class feedback for further improvements. Still, not all of the work during the educational process can be done by the teacher. Its effectiveness does depend on the learner as well. In order to contribute to their own learning, students should be: aware of the facilitative conditions implemented for their benefit, aware that the problem to be learned is realistic, relevant and meaningful motivated, since motivation is, according to Rogers, a tendency towards self-actualization present in all healthy individuals. If all the necessary conditions are satisfied, "learning becomes life, and a very vital life at that. The student is on his way, sometimes excitedly, sometimes reluctantly, to becoming a learning, changing being. "Reported positive results of Rogers' theory in practice include: fewer disciplinary problems in the classroom, better knowledge and IQ test scores, usage of higher levels of thinking, fewer acts of vandalism, positive self-regard, increase in creativity and others [6].

Additional aspects of this approach consist of a knowledge that individuals have an essential ambition to learn. Facilitative teachers are less protective of their constructs and beliefs than other teachers; more able to listen to learners, specifically to their reactions; tending to pay as much concetration to their communication with learners as to the subject of the course; inclined to accept feedback, two together positive and negative and to use it as useful understanding into themselves and their behaviour. Students are encouraged to take responsibility for their own learning; contribute much of the input for the learning which appears through their understanding and experiences; also learners are inspired to consider that the most valuable development is self-development and that learning needs to focus on factors that provide to resolving important disputes or achieving important outcomes. The facilitators ' task is to support learners to do their best rationalazing. The facilitators organize an atmosphere where everyone is encouraged to participate, understand one another's point of view and share responsibility. A group facilitator helps learners to search for appropriate solutions and create sustainable agreements.

As they say training and facilitating are two different activities. They require some of the same skills, and some different skills. A trainer is often a content expert, while a facilitator is a process expert. A trainer uses lecture, conducts demonstrations, supervises skill practice, and corrects the 
learners' mistakes. A meeting facilitator leads discussions and helps participants learn from their own experiences and shared information. The trainer might lead a discussion about course content; a facilitator will focus more on the process of a discussion. Facilitation skills training often includes training skills.

Facilitator focus of on how the discussion progresses to hold the group together and foster ownership; attention is on methods and process, participation of all, group dynamics; knowledge needed includes group dynamics expertise. Competencies of facilitators hould include: plan meetings using an agenda; set a productive climate and begins a discussion; gets the group to focus on defining and reaching outcomes; helps group communicate effectively; supports and encourages participation; fosters self-discovery of alternatives and solutions; helps the group make decisions; helps select a team leader; handles disruptive participants effectively excluded from the group Carl Rogers and others have developed the theory of facilitative learning. The basic premise of this theory is that learning will occur by the educator acting as a facilitator, that is by establishing an atmosphere in which learners feel comfortable to consider new ideas and are not threatened by external factors [7].

Conclusions. Analysis of foreign studies on the implementation of facilitation in the educational process showed that due to the specific principles and methods of the phenomenological model, the teacher receives the opportunity to most humanely construct his relation to the values of education, and through their understanding - to the student. In this regard, there is a new tool in pedagogical activity: the content search method of understanding and transforming pedagogical phenomena. Implementation of facilitation in the training of specialists is carried out in the following main directions: work on the development of the faculty qualities of teachers, students and the creation of appropriate conditions for the faculty interaction in the educational process. The teacher's professional position reflects a valuable attitude to pedagogical activity and its results, participants in the educational process. Provides conditions for the implementation of professional functions during solving pedagogical tasks. The educational process imposes a certain framework on the use of facilitation, which should not be regarded as a restriction, but rather as a specific innovative form of education and education with a priority in choosing a person to realize his own potential.

References

1. Heron, J. (1989) The Facilitator's Handbook. London: Kogan Page.432 p.

2. HunterD., \& Thorpe S. (2005). Facilitator values and ethics. In S. Schuman (Ed.), The IAF handbook of group facilitation: Best practices from the leading organisation in facilitation (pp. 545-561). San Francisco: JosseyBassMerriam-Webster Dictionary

3. Rogers, C. (1983) Freedom to Learn for the 1980's (2nd edition). Columbus, $\mathrm{OH}$ : Merrill.370p.

4. Rogers, C. (1969)Freedom to Learn.358p.

5. Rogers, C. (1961) On becoming a person. Boston: Houghton Mifflin.27p.

6. Patterson, C. H.(1977). Carl Rogers and Humanistic Education. In Foundations for a Theory of Instruction and Educational Psychology, Chapter 5. Harper \& Row,

7. Stapley, L. (1996) The Personality of the Organisation: A Psycho-DynamicExplanation of Culture and Change. London: Free Association Books.250 p

8. The theory \& practice of teaching / edited by Peter Jarvis 2002.Simultaneously published in the USA and Canadaby Routledge 270 Madison Ave, New York, 277p. надійшл до редколегії 28.05.19

Л. Бахмач, канд. пед. наук,

Київський національний університет імені Тараса Шевченка, Київ, Україна

\section{ПОНЯТТЯ ТА СУТНІСТЬ ФАСИЛІТАЦІЇ У ДОСЛІДЖЕННЯХ ЗАРУБІЖНИХ УЧЕНИХ}

Наведено результати узагальнення існуючої інформації щодо використання фасилітації, зроблено обмежений історичний екскурс дослідження феномену фасилятивності та наведено розуміння його сутності в освітньому процесі тощо. Важливим напрямком дослідження фасилітації в навчальному процесі є вивчення фасилятивних якостей викладача, вчителя, педагога. До педагогічної фасилітації відносимо характеристики, мотиви, настанови, емоції, спрямованість особистості вчителя - його індивідуальні особливості як суб'єкта педагогічної фасилітації: прагнення допомагати іншим людям, здатність до співчуття та співпереживання, доброзичливість, емоційна чутливість, ціннісне ставлення до особистості іншої людини, прагнення до роботи з дітьми, ціннісне ставлення до внутрішнього світу дитини, справедливість, здатність відчувати дитину, почуття радості від роботи з дітьми, бажання цінувати і примножувати вічні людські цінності в освітній і виховній діяльності. Педагогічна фасилітація є специфічним видом педагогічної діяльності викладача, яка має на меті допомагати студенту в саморозвитку, самореалізації, самовдосконаленні, сприяти його особистісному зростанню, розкриттю здібностей, пізнавальних можливостей. Технології фасилітації в освітньому процесі закладу вищої школи застосовуються з метою підвищення позитивної мотивації, активізації комунікативної діяльності студентів, набуття ними досвіду вирішення особистих і професійних проблем комунікації; створення умов конструктивної взаємодії із суб'єктами навчально-виховного процесу, забезпечення сприятливого морально-психологічного клімату; вирішення й запобігання конфліктним ситуаціям професійної взаємодії. Фасилітативна педагогічна технологія є сукупністю принципів діяльності фасилітатора та способів їх реалізації в освітньому просторі.

Ключові слова: фасилітація, вчитель-фасилітатор, фасилітатор, Карл Роджерс, педагогічна діяльність. 